\title{
U-Pb zircon ages of Mesozoic plutons in the Damyang-Geochang area, Ryongnam massif, Korea
}

\author{
ANDREW TUREK ${ }^{1}$ and CHEONG-BIN KIM ${ }^{2}$ \\ ${ }^{1}$ Department of Earth Sciences, University of Windsor, Windsor, Ontario, Canada N9B 3P4 \\ ${ }^{2}$ Department of Geology, Chonnam National University, 300 Yongbong-dong, Puk-ju, Kwangju, Korea 500-757
}

(Received February 15, 1995; Accepted May 2, 1995)

The Damyang-Geochang area in the southwestern part of the Ryongnam massif, Korea, is composed of Precambrian gneisses that have been intruded by Triassic to Jurassic, felsic to mafic, batholiths and stocks. Since the Triassic this area has been affected by four orogenies. Eight $\mathrm{K}-\mathrm{Ar}, \mathrm{Ar}-\mathrm{Ar}$, and $\mathrm{Rb}-\mathrm{Sr}$ ages have previously been reported for some of the rocks in the area, and the ages range from 159 to 228 Ma.

This study reports the first U-Pb zircon ages for the Korean peninsula. In the Damyang-Geochang area, Mesozoic plutonism appears to span the period from $219 \mathrm{Ma}$ to $176 \mathrm{Ma}$. The first period of Mesozoic plutonism resulted in the emplacement of the (unnamed) foliated granite, the foliated gabbro, and the Daegang foliated granite, at 219-212 Ma. The second plutonic event occurred at 187-183 Ma, in which a foliated granodiorite and the Sunchang foliated granite were emplaced. In the third plutonic event the Namweon granitic batholith and an associated diorite stock, both non-foliated and post-tectonic, were emplaced at 177-176 Ma. Concordia plots indicate derivation of these plutonic rocks from a Precambrian protolith, 1.9-2.6 Ga in age. $\mathrm{Pb}$ isotopic compositions measured on feldspars have an upper crustal signature. A porphyroblastic gneiss from the Precambrian basement yields a zircon age of $1935 \mathrm{Ma}$.

\section{GEOLOGICAL BACKGROUND}

The Korean peninsula is situated between the North China platform and the Japanese volcanic arc, and sits on the northeast Asian plate which borders the active Pacific plate. The rocks of the Korean peninsula are Archean to Holocene and have been involved in several orogenies, from Precambrian to Cenozoic. These orogenies involved tectonic movement, metamorphism and igneous intrusion, and produced distinct geologic terrains. In south Korea there are five such structural provinces: Kyonggi massif, Ryongnam massif, Okchon fold belt, Kyongsang basin and Pohang basin (Fig. 1). The major tectonic periods of the Phanerozoic that affected the Korean peninsula are: 1) the Great Hiatus (Ordovician-Carboniferous), 2) the Songnim Disturbance (Triassic), 3) the Daebo Orogeny (Jurassic), 4) the Bulguksa Disturbance (Cretaceous), and 5) the Yonil Dis- turbance (Tertiary-Quaternary). Most of the Mesozoic plutonic rocks of the Korean peninsula were emplaced during the Jurassic and Cretaceous orogenies and are commonly referred to as the Daebo granites and the Bulguksa granites, respectively.

The Damyang-Geochang area (Fig. 2) is in the southwest part of the Ryongnam massif which is comprised of an undivided Precambrian Gneiss Complex, metasedimentary rocks of unknown age, foliated gabbro, foliated granites, and the non-foliated Namweon granite and diorite. The regional foliation trends northeast-southwest, which is the same as in the Okchon fold belt zone (Kim and Kim, 1984; Hong and Lee, 1989; Kim et al., 1991).

The Precambrian Gneiss Complex is a mixture of metasedimentary and metaigneous rocks. The metasedimentary series is made up of metapelite, banded gneiss, granitic gneiss, and crystalline 


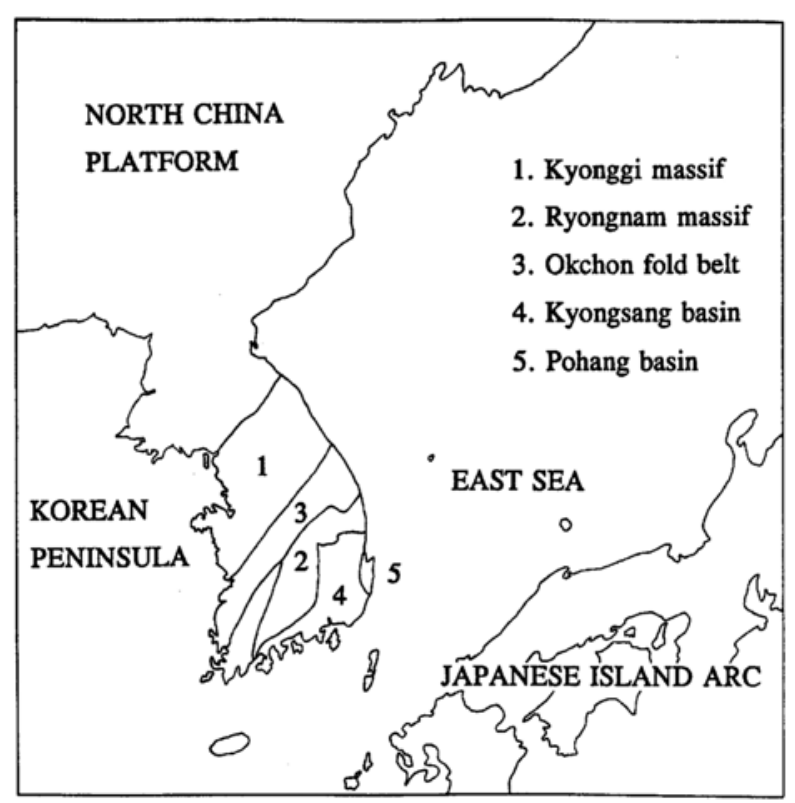

Fig. 1. Structural provinces of the Korean peninsula.

schist. The granitic gneisses include granoblastite, migmatitic gneiss, and porphyroblastic gneiss. These granitic gneisses can be further distinguished by the amount of granitic component introduced during the granitization and migmatization process (Lee, 1973, 1980). The metaigneous series includes a mafic plutonic complex, metagabbro, metadiorite, metaanorthosite, and felsic plutonic rocks that are now orthogneisses. The orthogneisses recognized are: hornblende gneiss, leucocratic biotite gneiss, and leucocratic granitic gneiss. There is, however, some controversy and lack of agreement on the para- and ortho-gneiss designation.

The Precambrian Gneiss Complex is intruded by Mesozoic mafic to felsic plutonic rocks. A mafic complex that intrudes the gneisses (Fig. 2) is composed of anorthosite, foliated gabbro, and diorite. The dominant rock is the foliated gabbro and it is medium- to coarse-grained, occasionally pegmatitic, with large euhedral hornblende and pyroxene crystals. The foliation conforms to the regional trend.

The foliated granites of the southwest
Ryongnam massif form a batholith, about $250 \mathrm{~km}$ long and 1 to $20 \mathrm{~km}$ wide, subparallel to the Okchon fold belt. The batholith is intrusive into the Precambrian Gneiss Complex along its west margin (Fig. 2) whereas the western contact of the batholith is covered by Cretaceous volcanic rocks which places a minimum age on this body. There are several varieties of the foliated granites identified. The more important ones are the Daegang foliated granite and granodiorite, Sunchang foliated granite and undivided foliated granitoids, and a two-mica foliated granite (Fig. 2). Major element chemical data show that the Sunchang, undivided, and two-mica foliated granites belong to the calc-alkalic series, whereas the Daegang foliated granite shows tholeiitic affinities. Trace elements, REE, and $(\mathrm{La} / \mathrm{Lu})_{\mathrm{CN}}$, $\mathrm{Eu} / \mathrm{Sm}$ ratios for the above felsic plutonic rocks are, according to Kim and Kim $(1988,1990)$, Kim (1990), and Kim et al. (1990), characteristic of plutonism in a continental margin and volcanic arc setting. The foliation is attributed by Hong and Lee (1989) and Kim and Kim (1990) to ductile deformation at depth related to a dextral strike- 


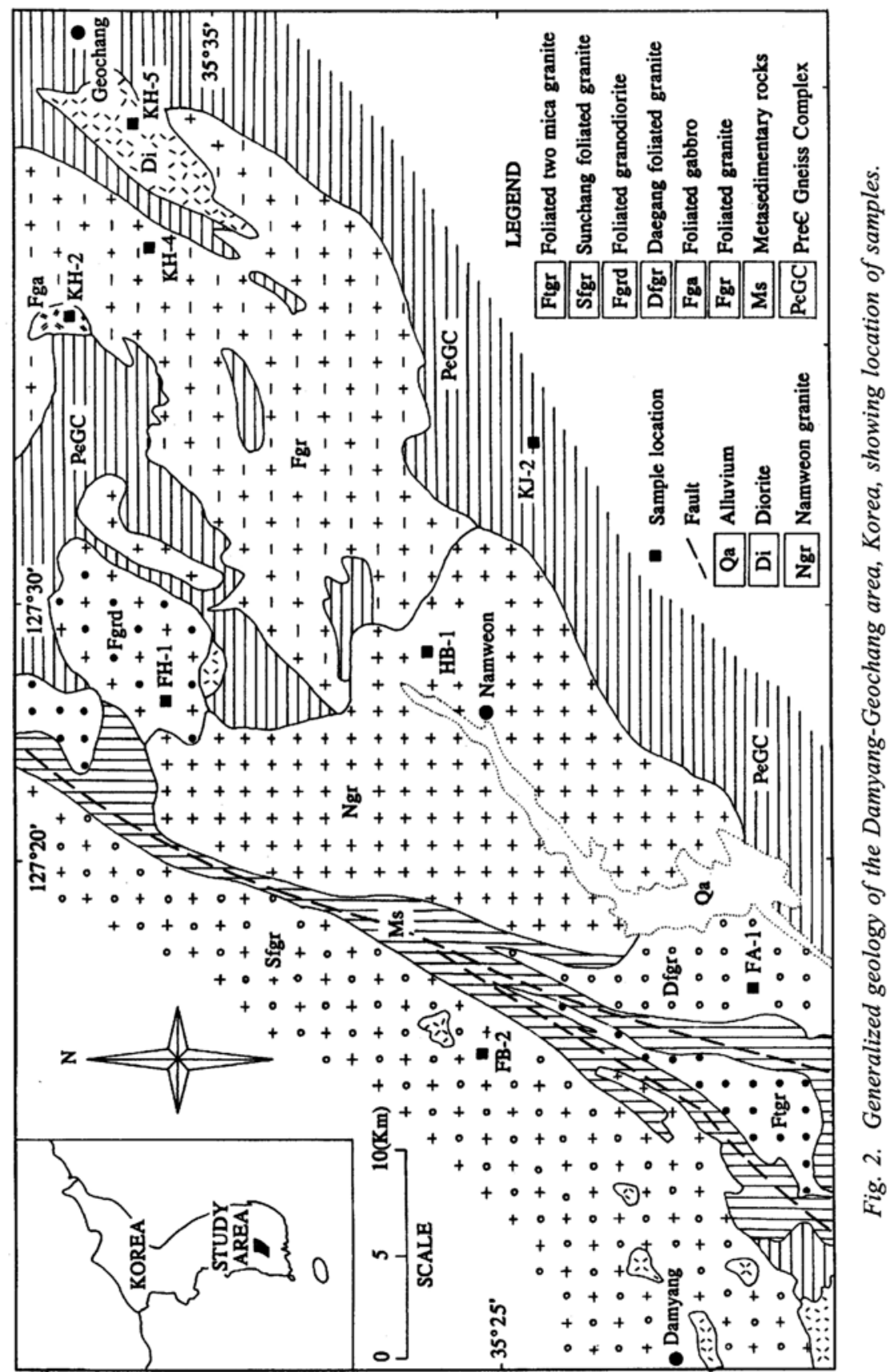



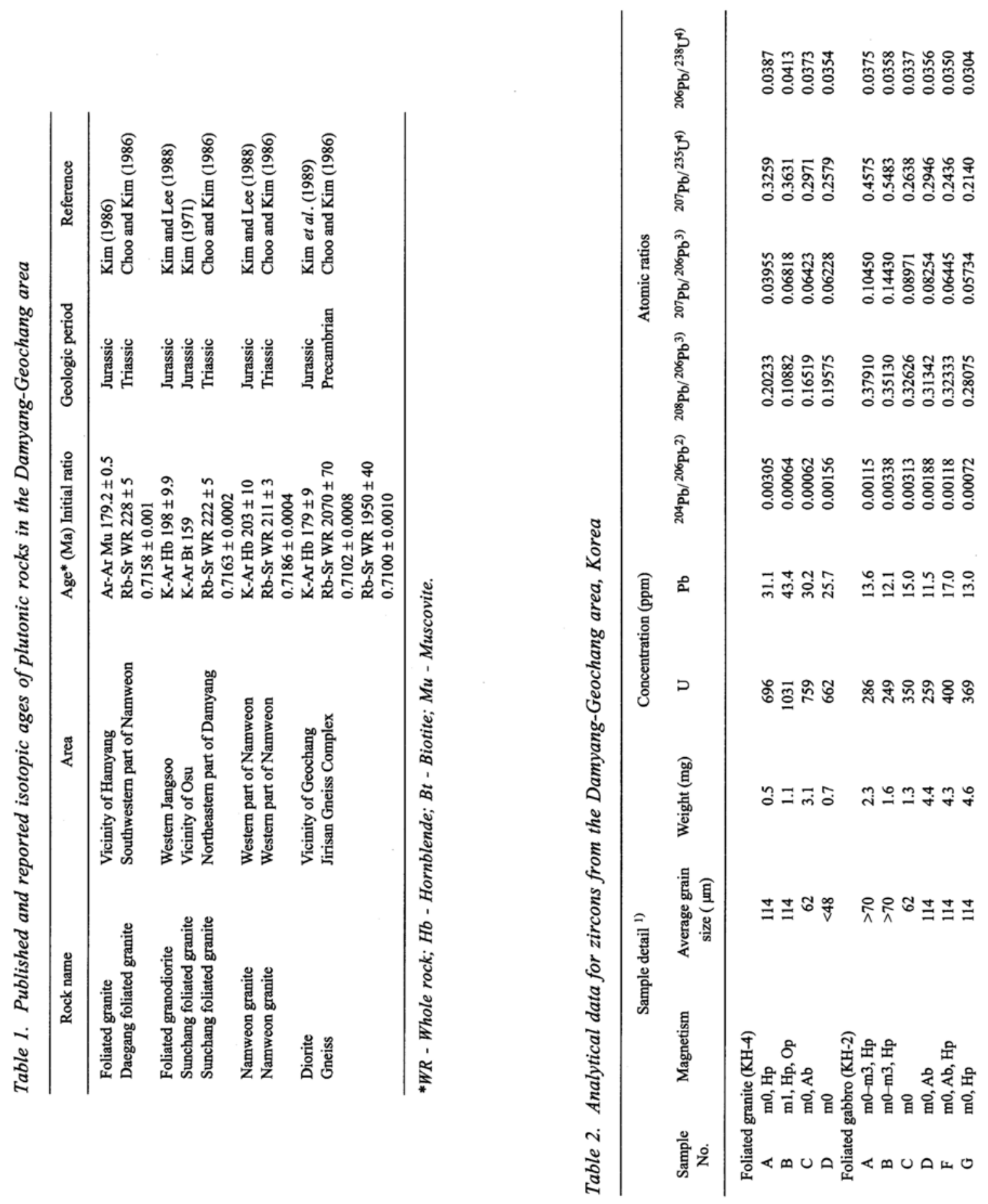


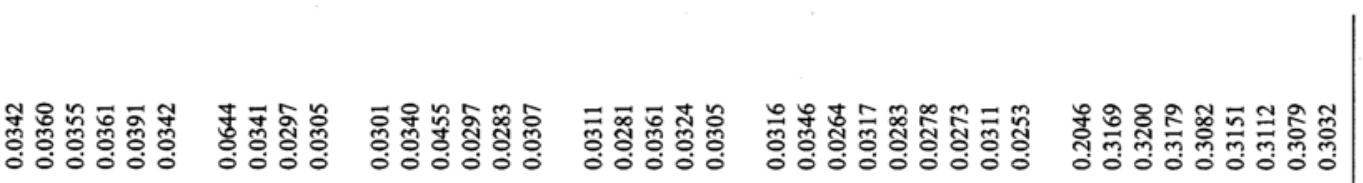

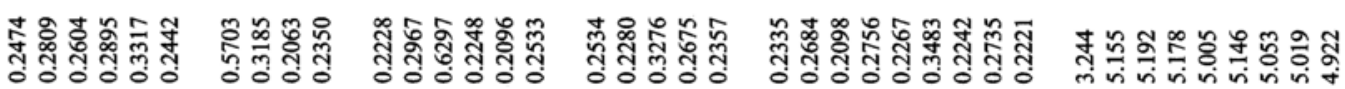

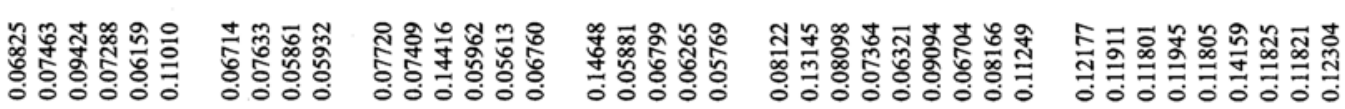

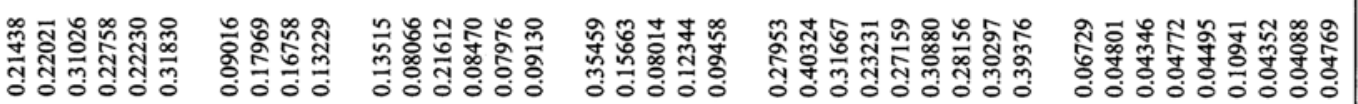

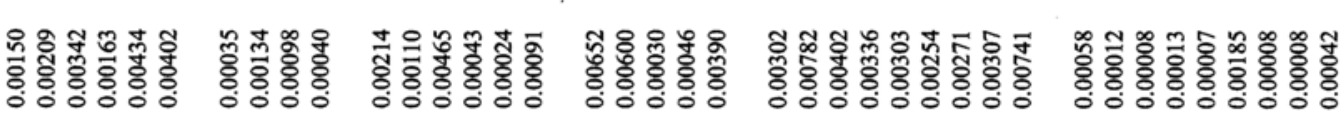

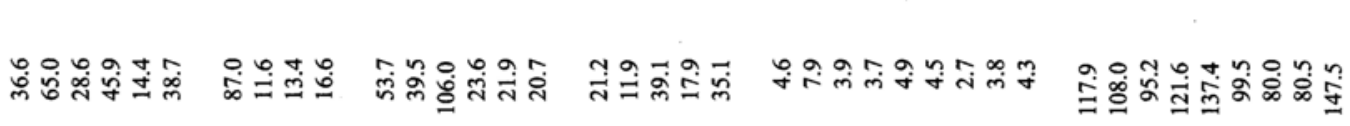

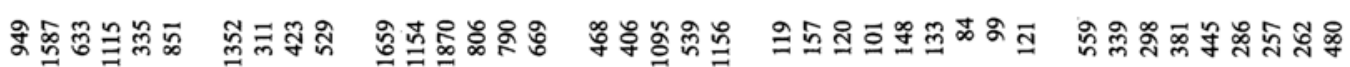

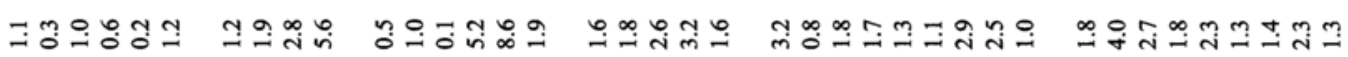

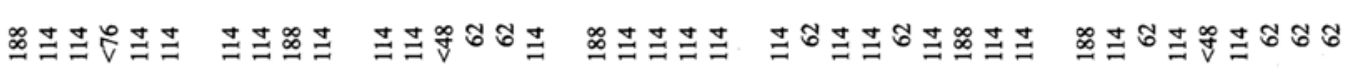
离
焉 
slip fault.

The Namweon granite batholith (Fig. 2) is a coarse-grained, massive non-foliated body, intrusive into the gneiss complex and into the foliated granites. Four rock types are recognized: hornblende biotite granodiorite, porphyritic granite, biotite granite, and a two-mica granite. Chemical evidence, major and trace elements, and REE, indicates that this body is also calcalkalic and related to continental plate margin plutonism (Hong et al., 1988; Kim and Kim, 1990). There are several scattered small stocks of diorite to gabbro that are regarded as related to the Namweon granite.

Isotopic age determinations by the $\mathrm{Rb}-\mathrm{Sr}, \mathrm{K}$ $\mathrm{Ar}$, and $\mathrm{Ar}-\mathrm{Ar}$ methods for rocks in and adjacent to the Damyang-Geochang area have been published or reported by Choo and Kim (1986), Kim (1971, 1986), Kim and Lee (1988), Kim et al. (1989). These ages, some of which are preliminary, are summarized in Table 1 . This study presents the first $\mathrm{U}-\mathrm{Pb}$ zircon ages for the Korean peninsula, and also evaluates the systematics of this isotopic system as applied to a relatively young, yet complicated geologic terrain.

\section{Analytical Procedures}

The zircon separations were done by standard methods using the Wilfley table, the Carpco and Frantz magnetic separators, and heavy liquids. All zircon fractions were upgraded by handpicking and by mild abrasion (Krogh, 1982). In addition some fractions were subsequently strongly abraded. They were cleaned by repeated ultrasound vibration in
$50 \%$ nitric acid and ultrapure water. Plagioclase feldspars were separated from each of the Mesozoic samples. The zircon dissolution using $\mathrm{HF}$ and $\mathrm{HNO}_{3}$ acids was done using the methods of Krogh (1973) and Parrish (1987). Similar procedure was used for the feldspar dissolution, for which samples size was $15-20 \mathrm{mg}$. $\mathrm{U}$ and $\mathrm{Pb}$ concentrations were determined on aliquots spiked with ${ }^{235} \mathrm{U}$ and ${ }^{208} \mathrm{~Pb}$ tracers, while $\mathrm{Pb}$ isotopic composition was measured on unspiked aliquots. More details of the laboratory procedures can be found in Turek et al. (1992).

The isotopic ratios were measured on a $90^{\circ}$ $25-\mathrm{cm}$ solid-source single-collector mass spectrometer at University of Windsor (Table 2). Mass fractionation based on values obtained for National Bureau of Standards isotopic standards was determined and used as $0.10 \%$ per atomic mass unit. The analytical uncertainty for unspiked $\mathrm{Pb}$ run is $0.1 \%(2 \sigma)$ for both the ${ }^{207} \mathrm{~Pb} /{ }^{206} \mathrm{~Pb}$ and ${ }^{208} \mathrm{~Pb} /{ }^{206} \mathrm{~Pb}$ and less than $\pm 0.000010(2 \sigma)$ for ${ }^{204} \mathrm{~Pb} /{ }^{206} \mathrm{~Pb}$ depending on the ${ }^{204} \mathrm{~Pb}$ content. Laboratory blank was 80 or $15 \mathrm{pg} \mathrm{Pb}$, depending on the size of the dissolution vessel used, having a composition of ${ }^{206} \mathrm{~Pb} /{ }^{204} \mathrm{~Pb}=18.7,{ }^{207} \mathrm{~Pb} /{ }^{204} \mathrm{~Pb}=15.7,{ }^{208} \mathrm{~Pb} /{ }^{204} \mathrm{~Pb}$ $=38.4$. Common $\mathrm{Pb}$ correction was made using the isotopic composition of $\mathrm{Pb}$ as determined in the feldspars for each of the Mesozoic samples (Table 3) and by using the Stacey and Kramers (1975) values for the Precambrian sample. The data reduction followed the procedure of Ludwig (1982). The regression analyses were done using the computer program of Ludwig (1992). The input errors used were $1 \%(2 \sigma)$ for the $\mathrm{U} / \mathrm{Pb}$ ratios,

Table 3. Isotopic composition of lead in feldspars from the Damyang-Geochang area

\begin{tabular}{lccc}
\hline \multicolumn{1}{c}{ Sample } & ${ }^{206} \mathrm{~Pb} /{ }^{204} \mathrm{~Pb}$ & ${ }^{207} \mathrm{~Pb} /{ }^{204} \mathrm{~Pb}$ & ${ }^{208} \mathrm{~Pb} /{ }^{204} \mathrm{~Pb}$ \\
\hline KH-4 Foliated granite & 17.696 & 15.611 & 38.291 \\
KH-2 Foliated gabbro & 18.836 & 15.989 & 39.490 \\
FA-1 Daegang foliated granite & 17.665 & 15.604 & 38.077 \\
FH-1 Foliated granodiorite & 18.034 & 15.799 & 39.223 \\
FB-2 Sunchang foliated granite & 18.911 & 16.234 & 40.044 \\
HB-1 Namwean granite & 17.915 & 15.665 & 38.783 \\
KH-5 Diorite & 18.409 & 16.058 & 40.596 \\
\hline
\end{tabular}


and covariance correlation of 0.95 . The Ludwig (1992) regression is taken as being within experimental error when the probability of fit is $15 \%$ or higher, in which case this yields a so-called Model 1 age. For a probability of less than $15 \%$ the Model 2 age, which recognizes an error greater than experimental, is accepted. The errors reported with the ages are $95 \%$ confidence limits. The decay constants used were those recommended by Steiger and Jäger (1977).

\section{RESULTS}

In this study we report on $\mathrm{U}-\mathrm{Pb}$ zircon ages for eight rock units, based on analyses of 49 zircon fractions. The location of the samples is shown in Fig. 2 with coordinates given in the Appendix. The zircon analytical data is given in Table 2 and shown as concordia plots in Figs. 3-10. The isotopic composition of the $\mathrm{Pb}$ determined for the feldspars in the seven rocks is given in Table 3 and shown as a $\mathrm{Pb}-\mathrm{Pb}$ plot in Fig. 11. Table 4 gives the concordia ages.

\section{Foliated granite ( $\mathrm{KH}-4)$}

This foliated granite is of batholithic proportions, it intrudes the Precambrian Gneiss Complex, and in turn is intruded by foliated and non-foliated igneous rocks. The separated zircons are euhedral, transparent, clear to milky, with minor fractures. Three clear fractions and a fourth handpicked fraction that is milky and slightly fractured were analyzed. The three clear fractions define a discordia within experimental error (Fig. 3). The probability of fit is $99 \%$. The excluded point, B, is the milky fraction, which has the highest $U$ and $\mathrm{Pb}$ concentration and noticeably lower ${ }^{208} \mathrm{~Pb} /{ }^{206} \mathrm{~Pb}$ compared to fractions A, C, and D (Table 2). The concordia lower intercept is $219.2 \pm 2.9 \mathrm{Ma}$ with an upper intercept at $2237 \pm 176 \mathrm{Ma}$. Hence the age for this rock is $219 \pm 3 \mathrm{Ma}$.

\section{Foliated gabbro ( $\mathrm{KH}-2)$}

This small plug intrudes the Precambrian Gneiss Complex and the foliated granite. The zircons in this rock are anhedral but of excellent quality, and there are very few cloudy or fractured grains. Anhedral habit of zircons in a gabbro is somewhat unusual, consequently we confirmed their identity by X-ray. Analyses of six zircon fractions show a very large scatter on the concordia plot (Fig. 4). A line could be fitted to points $\mathrm{C}, \mathrm{D}$, and $\mathrm{G}$, but the resulting age would be too young for observed structural field relations,

Table 4. Summary of zircon age determinations for the Damyang-Geochang area, Korea

\begin{tabular}{|c|c|c|c|c|}
\hline \multirow{2}{*}{$\begin{array}{r}\text { Sample } \\
\text { KH-4 Foliated granite }\end{array}$} & \multicolumn{2}{|c|}{ Concordia intercepts (Ma) } & \multirow{2}{*}{$\begin{array}{l}\text { Comments* } \\
\begin{array}{l}\text { Model } 1, \mathrm{P}=99 \%, \mathrm{MSWD}=0.0001 \\
\text { point B excluded }\end{array}\end{array}$} & \multirow{2}{*}{$\frac{\text { Age (Ma) }}{219 \pm 3}$} \\
\hline & $2237 \pm 176$ & $219.2 \pm 2.9$ & & \\
\hline KH-2 Foliated gabbro & & & Point $\mathrm{F}$ only, ${ }^{207} \mathrm{~Pb} /{ }^{206} \mathrm{~Pb}$ age & $219 \pm 3$ \\
\hline FA-1 Daegang foliated granite & $2025 \pm 475$ & $212.3 \pm 8.2$ & All 6 points, Model 2, MSWD $=11$ & $212 \pm 8$ \\
\hline FH-1 Foliated granodiorite & $2595 \pm 233$ & $186.9 \pm 2.6$ & $\begin{array}{l}\text { Model } 2, \text { MSWD }=1.5 \\
\text { point A excluded }\end{array}$ & $187 \pm 3$ \\
\hline \multirow[t]{2}{*}{ FB-2 Sunchang foliated granite } & $2628 \pm 245$ & $183.5 \pm 9.2$ & All 6 points, Model 2, MSWD $=42$ & \\
\hline & $2648 \pm 179$ & $182.6 \pm 8.0$ & $\begin{array}{l}\text { Model } 2, \mathrm{P}=48 \%, \text { MSWD }=9.1 \text {, } \\
\text { points } \mathrm{B} \text { and } \mathrm{F} \text { excluded }\end{array}$ & $183 \pm 8$ \\
\hline HB-1 Namwean granite & $1858 \pm 80$ & $176.0 \pm 2.8$ & $\begin{array}{l}\text { Model } 1, P=48 \%, \text { MSWD }=0.49 \text {, } \\
\text { points } \mathrm{A} \text { and } \mathrm{B} \text { excluded }\end{array}$ & $176 \pm 3$ \\
\hline KH-5 Diorite & $1164 \pm 127$ & $176.7 \pm 6.2$ & $\begin{array}{l}\text { Model } 1 \text {, points } \mathrm{C} \text { and } \mathrm{D} \text { only, } \\
\text { seven points excluded }\end{array}$ & $177 \pm 6$ \\
\hline KJ-2 Porphyroblastic gneiss & $1934.8 \pm 4.0$ & $150 \pm 27$ & Model $1, P=40 \%$, MSWD $=1$ & $1935 \pm 4$ \\
\hline
\end{tabular}

Notes: Decay constants used: $\lambda^{238} U=1.55125 \times 10^{-10}$ year ${ }^{-1}$ and $\lambda^{235} U=9.8485 \times 10^{-10}$ year $^{-1}$ (Steiger and Jager, 1977). Error terms of concordia ages are $95 \%$ confidence limits.

${ }^{*} P$ is probability of fit; MSWD, mean square of weighted deviates, as defined by Ludwig (1992). 


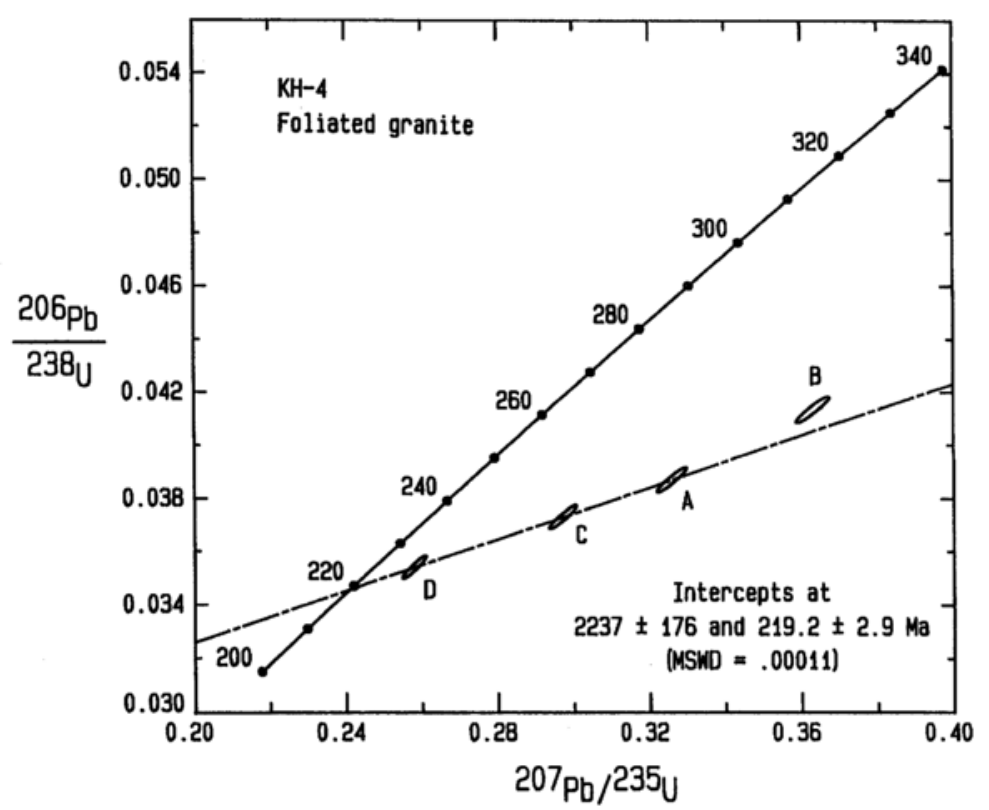

Fig. 3. Concordia diagram for $\mathrm{KH}-4$, foliated granite. Point $\mathrm{B}$ is excluded from the regression.

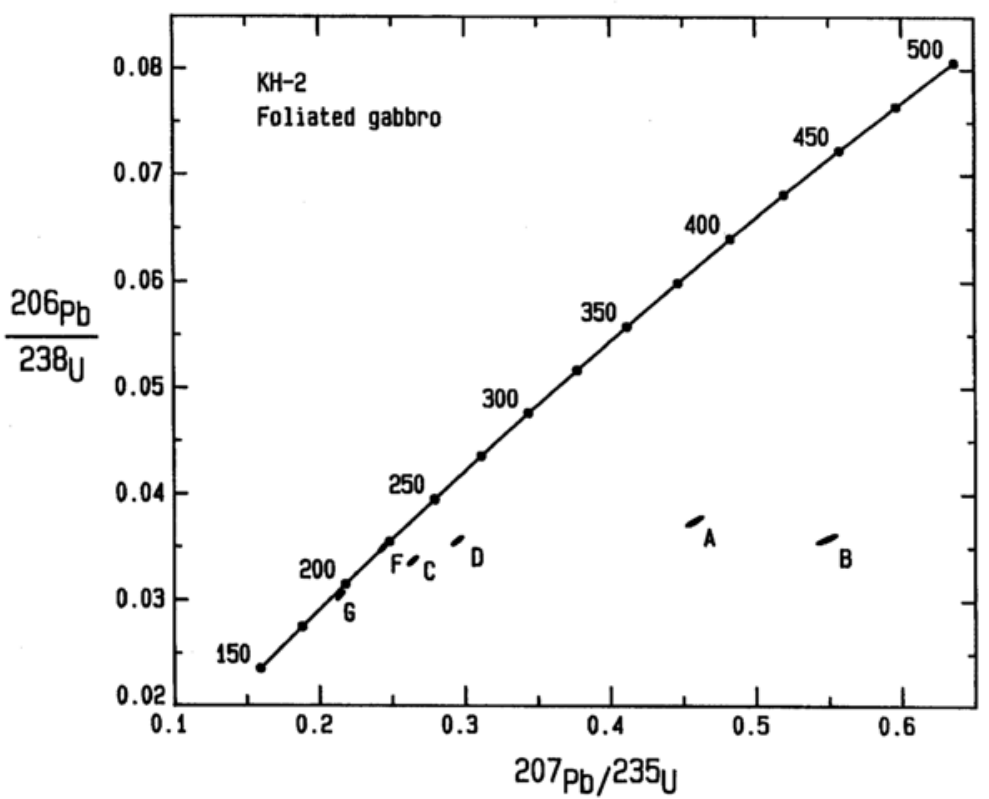

Fig. 4. Concordia diagram for $\mathrm{KH}-2$, foliated gabbro. Point $\mathrm{F}$ is concordant, age is $219 \mathrm{Ma}$.

moreover, such an interpretation would mean that the concordant data point $\mathrm{F}$ would have to be discarded. A regression of data points $\mathrm{C}, \mathrm{D}$, and $\mathrm{G}$ gives intercept ages, within experimental limits, of $189.7 \pm 2.4$ and $1733 \pm 95 \mathrm{Ma}$. However as point $\mathrm{F}$ is concordant, and also to conform to the local mapping we feel that $219 \pm 3 \mathrm{Ma}$ is the best estimate of the age for this rock. 
Daegang foliated granite ( $F A-1)$

The sample collected from this batholith is an alkali granite. It contains zircons, yellow to pale brown in colour. Six fractions were selected, five of these, A, B, C, D, F, were handpicked to be internally as homogenous as possible, the sixth fraction, E, is a bulk sample. Morphologically, the differences between the fractions are very slight, possibly fractions $\mathrm{B}$ and $\mathrm{E}$ are best quality, clearest and most euhedral, grains. The six points form a linear array with some scatter (Fig. 5), the data regression defines a lower intercept age of $212.3 \pm 8.2 \mathrm{Ma}$, and an upper intercept age of $2025 \pm 475 \mathrm{Ma}$. The discordia defined by fractions $\mathrm{A}, \mathrm{E}$, and $\mathrm{F}$ is within experimental error, has a probability of fit of $23 \%$, and gives an age of $211.9 \pm 1.9 \mathrm{Ma}$. However, we prefer to accept the more robust error estimate, hence, the age of this rock is $212 \pm 8 \mathrm{Ma}$.

\section{Foliated granodiorite ( $F H-1)$}

This coarse-grained, foliated granodiorite also intrudes the Precambrian Gneiss Complex. The zircons in this rock are a heterogeneous population, transparent, but range from clear, milky, to light brown. Fraction A is comprised of cracked, light brown grains, and on the concordia plot, Fig. 6 , it is an outlier. Compositionally, this fraction is high in $\mathrm{U}$ and $\mathrm{Pb}$ and has the lowest ${ }^{208} \mathrm{~Pb} /{ }^{206} \mathrm{~Pb}$ (Table 2). The other three fractions are clear; fraction $\mathrm{B}$ is gem quality, fraction $\mathrm{C}$ has some fractures and inclusions, and fraction $\mathrm{D}$ is a bulk sample of the clear grains. The three points yield a discordia line which intercepts the concordia at $186.9 \pm 2.6 \mathrm{Ma}$ and at $2595 \pm 233 \mathrm{Ma}$. This is a Model 2 age with a probability of fit of $7.2 \%$, which is a slightly larger error than experimental, however, point $\mathrm{C}$ is within error of concordia, and thus $187 \pm 3 \mathrm{Ma}$ is taken as the age of this rock.

\section{Sunchang foliated granite (FB-2)}

This is a coarse-grained granodiorite that intrudes the Precambrian Gneiss Complex and the metasedimentary rocks. The zircons separated are amber-brown, milky to clear, euhedral to subhedral. Fraction A grains are clear, elongate and of gem quality, while fraction B is amber and fractured, and the others are clear to milky. The six fractions scatter on the concordia plot, Fig. 7. The regression of all six data points gives a lower

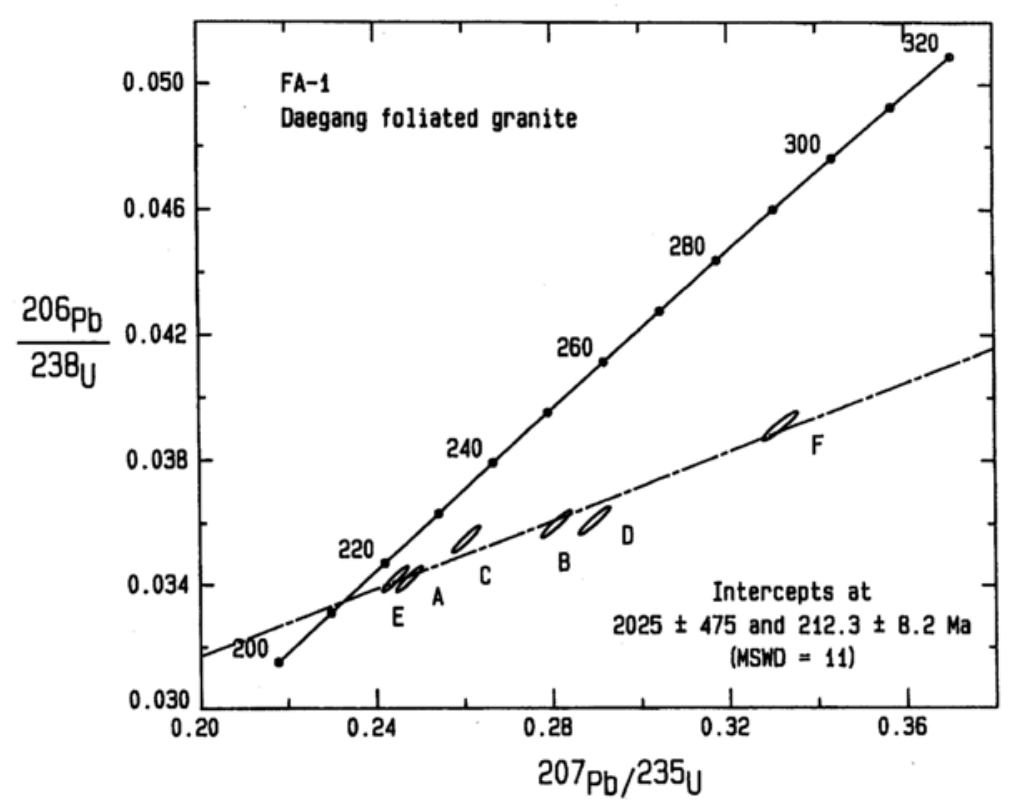

Fig. 5. Concordia diagram for FA-1, Daegang foliated granite. Regression line is fitted to all points. 


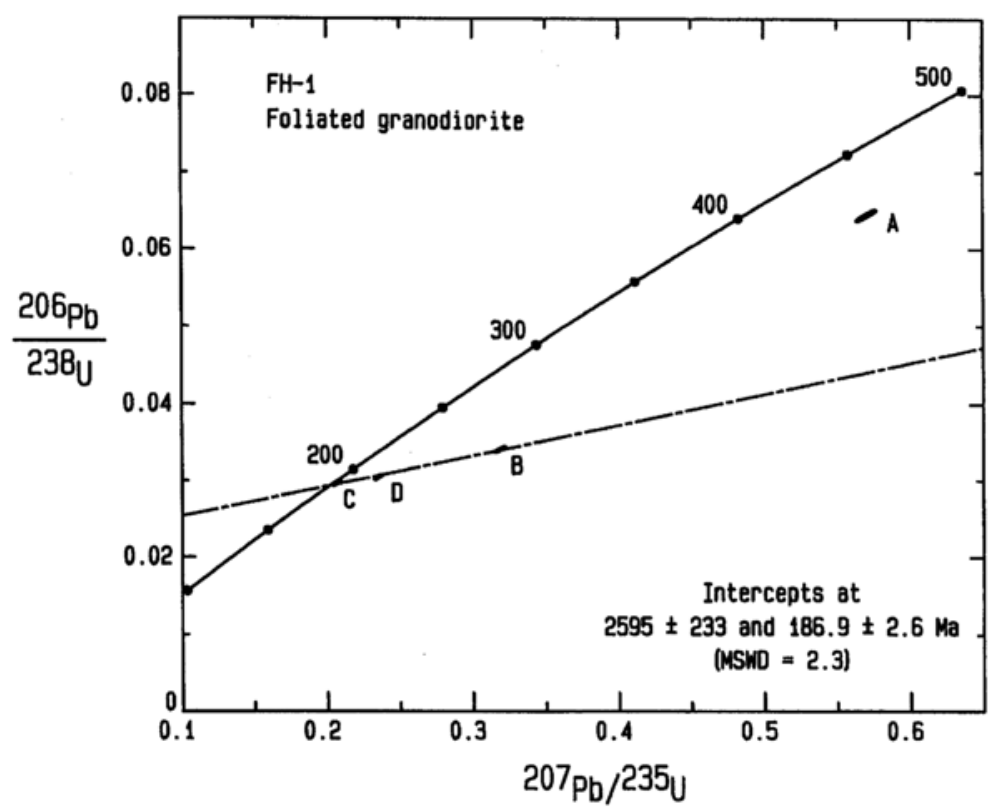

Fig. 6. Concordia diagram for FH-1, foliated granodiorite. Point A is excluded from the regression.

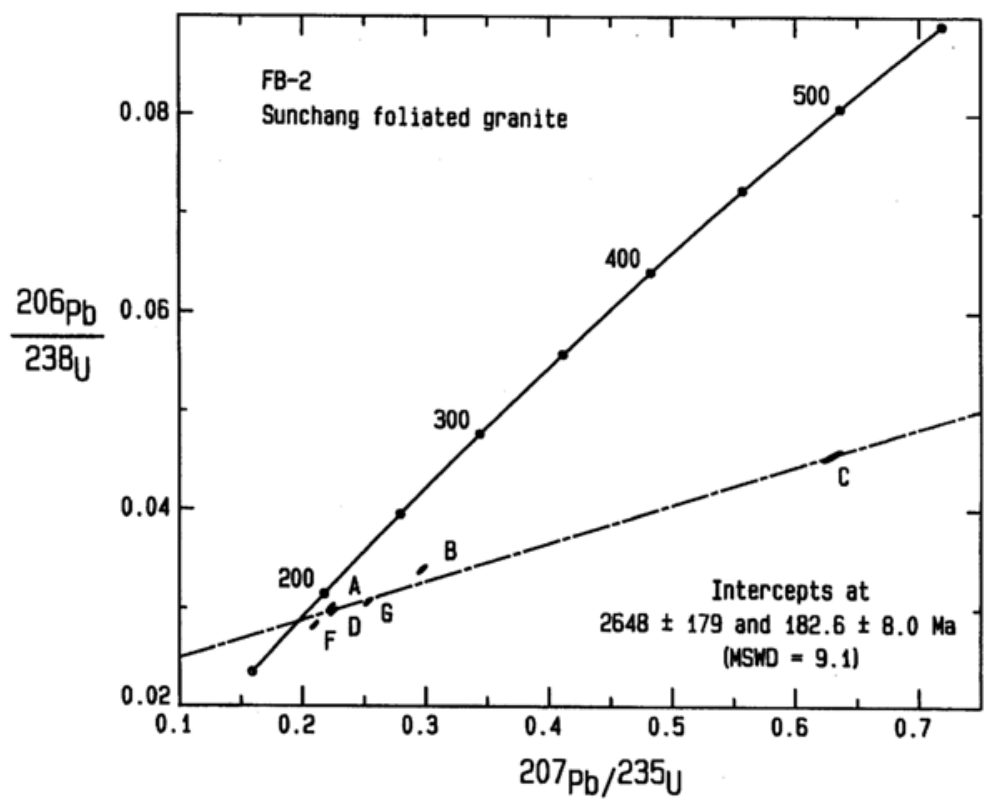

Fig. 7. Concordia diagram for FB-2, Sunchang foliated granite. Points $B$ and $F$ are excluded from the regression.

concordia intercept of $184 \pm 9 \mathrm{Ma}$, but, a better fit is obtained by excluding fractions $\mathrm{B}$ and $\mathrm{F}$, which are poorer quality, cracked and opaque grains. In this case the Model 1 regression inter- cepts are $182.6 \pm 8.0 \mathrm{Ma}$ and $2648 \pm 179 \mathrm{Ma}$. Hence, $183 \pm 8 \mathrm{Ma}$ is regarded as best estimate of the age of this rock. 
Namweon granite ( $H B-1)$

This is a non-foliated, fine-grained granite, which carries zircons that are brown, milky to clear, mostly euhedral, with some fracturing and some magnetite inclusions. The concordia plot (Fig. 8) shows that fractions G, F, and D are collinear yielding a lower concordia intercept age of $176 \pm 2.8 \mathrm{Ma}$ and an upper intercept of $1856 \pm$ $80 \mathrm{Ma}$. Points A and B, which have the lowest U and $\mathrm{Pb}$ concentrations, fall below the discordia. Point A zircons are of large grain size and fraction $\mathrm{B}$ zircons are strongly abraded but magnetic. Thus $176 \pm 3 \mathrm{Ma}$ is the assigned age for this body.

\section{Diorite (KH-5)}

This diorite stock near the town of Geochang is a medium to coarse grained, non-foliated body. It contains zircons of very good quality, clear or slightly milky, mostly euhedral, with very few cracks and no fractures, but most grains contain magnetite inclusions. A total of nine fractions was analyzed, and as seen on the concordia plot, Fig. 9 , the data have a large scatter. The oldest age that can be defined is by a discordia through points, $\mathrm{C}$ and $\mathrm{D}$, which are clear grains with mag- netite inclusions. However, the remaining seven fractions are not appreciably different; they are populations of clear to milky, euhedral to subhedral, with or without magnetite inclusions. In an attempt to create a concordant data point by very strong abrasion, we hand-picked and abraded fractions $\mathrm{K}$ and $\mathrm{L}$ with the expectation that $\mathrm{K}, \mathrm{L}$, $\mathrm{C}$, and D data would be collinear, but instead $\mathrm{K}$ and $L$ points are among those showing the greatest $\mathrm{Pb}$ loss. The discordia through the data points $\mathrm{C}$ and $\mathrm{D}$ gives concordia intercepts of $176.7 \pm 6.2$ $\mathrm{Ma}$ and $1164 \pm 127 \mathrm{Ma}$, and thus our interpreted age for this stock is $177 \pm 6 \mathrm{Ma}$.

\section{Porphyroblastic gneiss (KJ-2)}

A coarse grained porphyroblastic gneiss was collected from the Precambrian Gneiss Complex. It contains a very heterogeneous population of zircons. They range from colourless, through different shades of pink to brown, and they are euhedral, elongate to stubby. Because of this heterogeneity and also to obtain a spread of points on the discordia line nine fractions were analyzed (Fig. 10). Fraction A zircons which are the best quality grains, crystal clear, euhedral and elon-

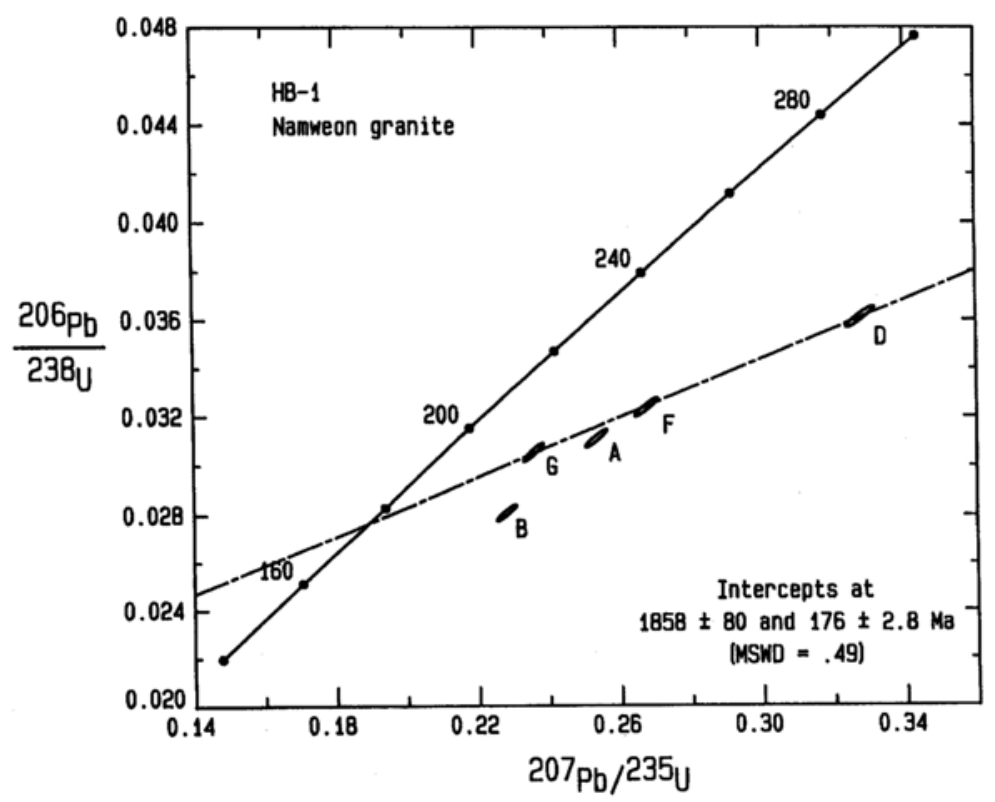

Fig. 8. Concordia diagram for HB-1, Namweon granite. Points $A$ and $B$ are excluded from the regression. 


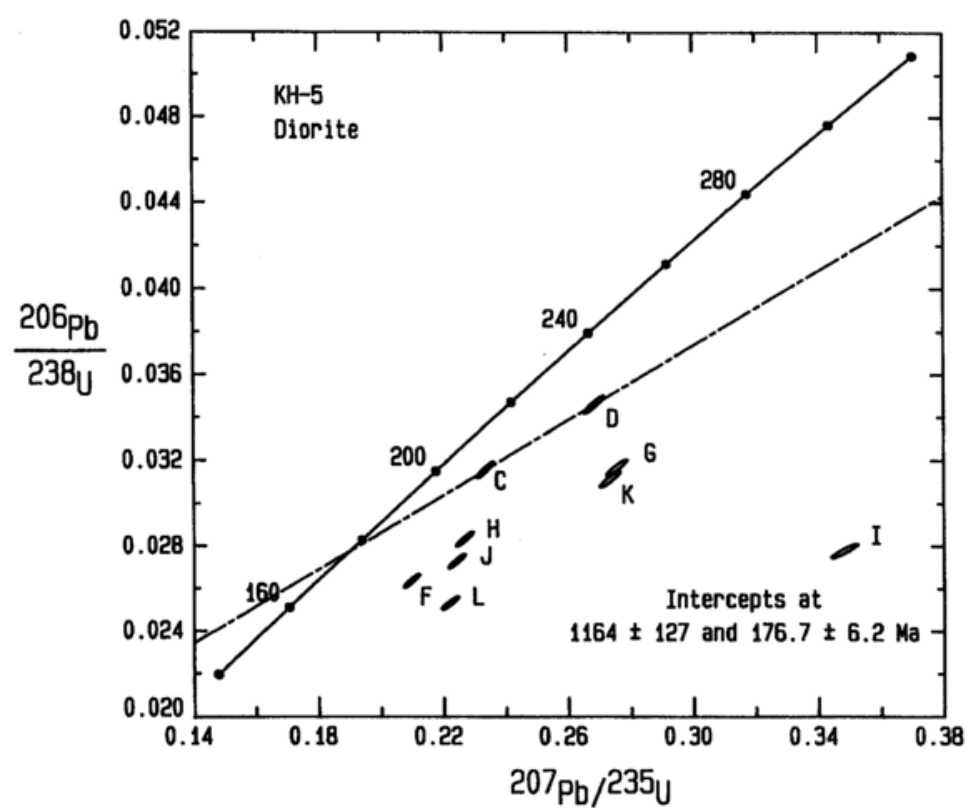

Fig. 9. Concordia diagram for $\mathrm{KH}-5$ diorite. The regression line shown is for points $C$ and $D$ only.

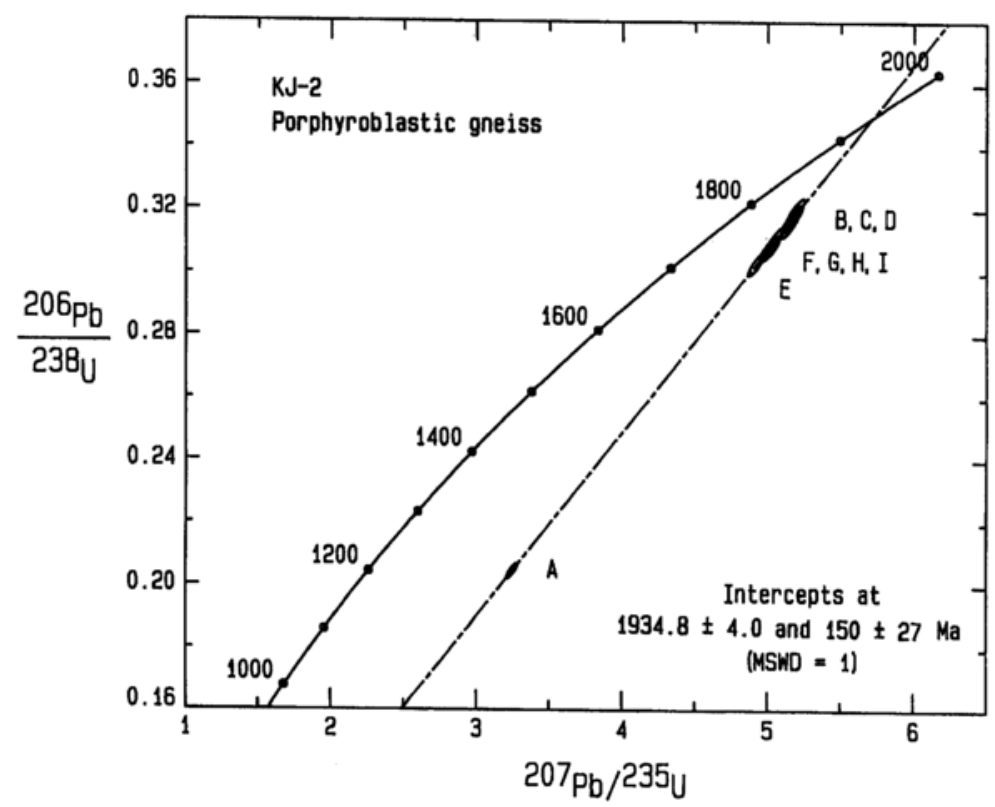

Fig. 10. Concordia diagram for KJ-2 Precambrian porphyroblastic gneiss.

gate, turned out to be $44 \%$ discordant. The other eight fractions were selected on a variety of colour and shape criteria and are $9-14 \%$ discordant. The regression of all nine data points is well within experimental error and gives concordia intercepts of $1934.8 \pm 4.0 \mathrm{Ma}$ and $150 \pm 27 \mathrm{Ma}$. Hence, the age of this member of the Precambrian Gneiss Complex is $1935 \pm 4 \mathrm{Ma}$. 


\section{Discussion}

Some zircons separated from the seven Mesozoic plutonic rocks from the Damyang-Geochang area in this study have experienced recent $\mathrm{Pb}$ loss. Analytical results indicate emplacement of these plutonic rocks between $176 \mathrm{Ma}$ to $219 \mathrm{Ma}$, and that they are derived from Precambrian, 1.9-2.6 $\mathrm{Ga}$, protolith. In addition this study establishes the existence of $1.9 \mathrm{Ga}$ basement in this area.

There are inherent problems in evaluating U$\mathrm{Pb}$ data that plot at the lower end of the concordia diagram. Recrystallized zircons commonly contain some of the original older component and generally plot along a discordia line. However, systematics of $\mathrm{Pb}$ loss (or $\mathrm{U}$ gain) can cause data points to plot below the discordia. Points that plot above the discordia may be derived from a different, younger, protolith or have experienced a different loss of $\mathrm{Pb}$ having been pre-conditioned in response to an older episodic $\mathrm{Pb}$ loss. Data points that plot below the discordia are most likely showing recent $\mathrm{Pb}$ loss, though other causes, such as loss of $\mathrm{Rn}$ will have the same effect. In this study we observe both effects, some data points plot above and some below the discordia, but most of the data points are collinear and define geologically meaningful ages.

The $\mathrm{U}-\mathrm{Pb}$ zircon ages indicate three sets of Mesozoic ages; some of the foliated plutons was emplaced at 219-212 Ma, a second set of foliated plutons came in at $187-183 \mathrm{Ma}$, a third set of plutons that are non-foliated formed at 177-176 Ma. Published and reported ages for these and similar rocks in the area by $\mathrm{K}-\mathrm{Ar}$ and $\mathrm{Rb}-\mathrm{Sr}$ are from 159 to $228 \mathrm{Ma}$ (Table 1).

The foliated granite, $\mathrm{KH}-4$, that we date at 219 $\mathrm{Ma}$, has a metamorphic Ar-Ar age of $179 \mathrm{Ma}$ (Kim, 1986). The Daegang foliated granite, FA-1, dated here at $212 \mathrm{Ma}$, has a $\mathrm{Rb}-\mathrm{Sr}$ isochron age of $228 \mathrm{Ma}$ (Choo and Kim, 1986), which we regard as reasonable agreement.

The second set of foliated granitic rocks we bracket at 187-183 Ma. The foliated granodiorite, $\mathrm{FH}-1$, has a U-Pb age of $187 \mathrm{Ma}$, and a hornblende K-Ar age of $198 \mathrm{Ma}$ (Kim and Lee, 1988).
The Sunchang foliated granite, FB-2, has a U-Pb age of $183 \mathrm{Ma}$, which is resolvably different than the $\mathrm{Rb}-\mathrm{Sr}$ isochron age of $222 \mathrm{Ma}$ reported by Choo and Kim (1986). The Rb-Sr isochron age is based on 11 data points, but the disposition of the points on the isochron is such that one point, having the lowest ${ }^{86} \mathrm{Sr}$ content, $4.4 \mathrm{ppm}$, and highest present day ${ }^{87} \mathrm{Sr} /{ }^{86} \mathrm{Sr}$ of 0.7506 , controls the slope of the isochron. The other 10 points have low ${ }^{87} \mathrm{Sr} /$ ${ }^{86} \mathrm{Sr}$ ratios, 0.7189 to 0.7262 , and plot close to the origin. We are not able to reevaluate statistically this isochron data as the $\mathrm{Rb}$ and $\mathrm{Sr}$ concentrations reported are rounded off to one decimal place; however by visual inspection it appears that a younger isochron could be constructed if the one enriched sample is excluded. This excluded point may lie on a parallel isochron, having same age but higher initial ratio; as these rocks are recycled material variability in initial ratios is likely.

The non-foliated Namweon granite, HB-1, has a U-Pb age of $176 \mathrm{Ma}$, and the non-foliated diorite, $\mathrm{KH}-5$, has an estimated age of $177 \mathrm{Ma}$. The hornblende $\mathrm{K}-\mathrm{Ar}$ ages for the Namweon granite and the diorite are $203 \pm 10$ and $179 \pm 9 \mathrm{Ma}$ (Kim and Lee, 1988; Kim et al., 1988), respectively. A Rb-Sr isochron age for the Namweon granite is $211 \pm 3 \mathrm{Ma}$ (Choo and Kim, 1986), which is significantly different from the $\mathrm{U}-\mathrm{Pb}$ age obtained here. The isochron age is based on 4 points, the disposition of the points is such that additional data points could rotate the isochron to a younger age comparable to the $176 \mathrm{Ma} \mathrm{U}-\mathrm{Pb}$ age.

The Precambrian porphyroblastic gneiss, KJ2 , gives a U-Pb zircon age of $1935 \mathrm{Ma}$. This compares with $\mathrm{Rb}-\mathrm{Sr}$ isochron ages obtained for two units in the Granitic Gneiss Complex of 2070 and $1950 \mathrm{Ma}$ by Choo and Kim (1986).

The systematics of the U-Pb, Rb-Sr, K-Ar systems, together with analytical and decay constant uncertainties, will produce differences in ages; particularly so, in a geologically complex area, such as this. In addition to the ages obtained here the upper intercepts of the concordia plots indicate derivation from a Precambrian protolith. These intercepts are 1.2-2.6 Ga, or 1.9-2.6 Ga if 


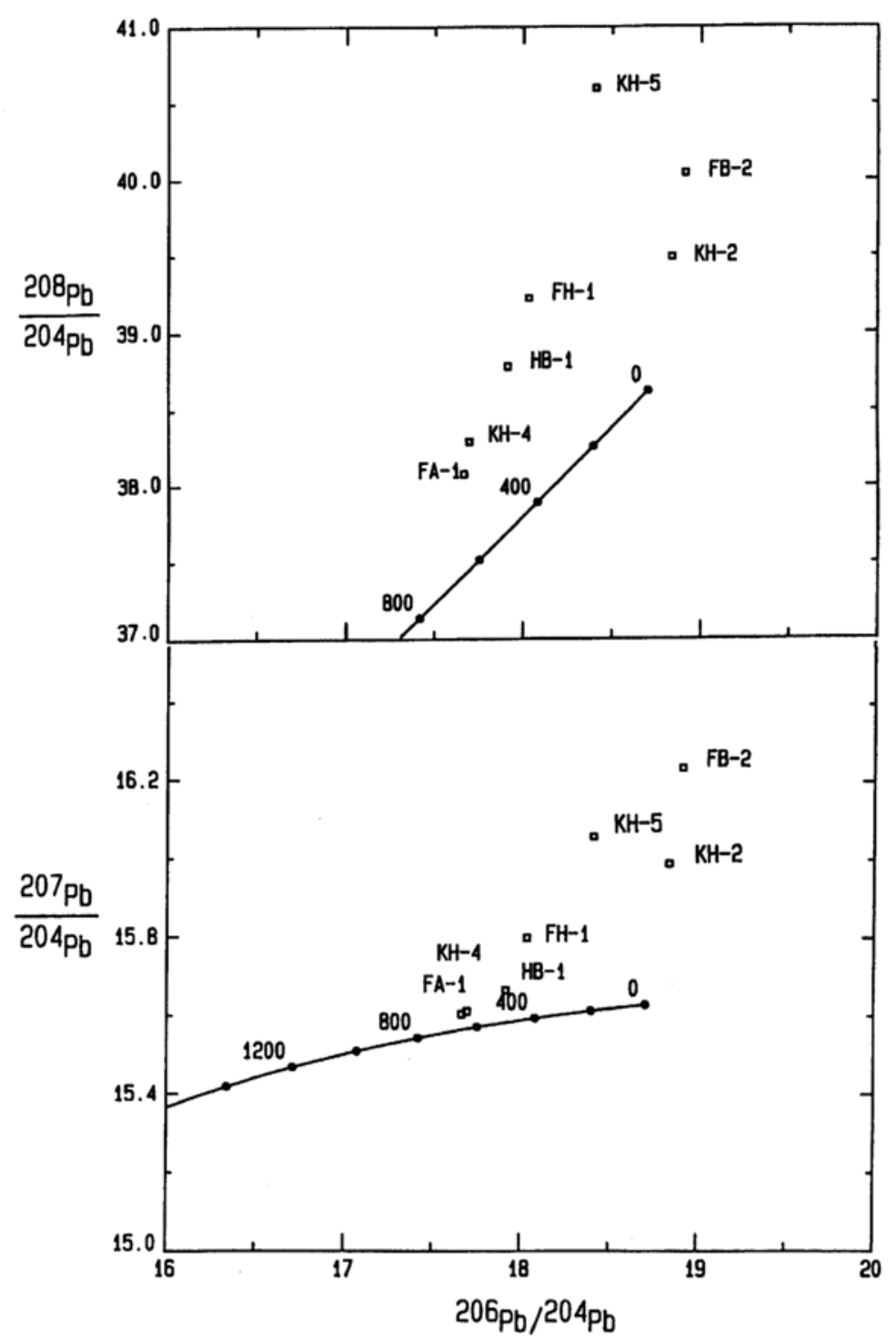

Fig. 11. Pb-Pb plot for feldspars. The reference curve is the Stacey and Kramers (1975) Pb isotope evolution curve.

the data for the diorite sample $\mathrm{KH}-5$ is disregarded because that upper intercept is based on only two data points. For the Mesozoic plutons we have measured the $\mathrm{Pb}$ isotopic compositions of feldspars (Table 3) in order to correct the zircon data for inherited $\mathrm{Pb}$. All seven data points plot above the Stacey and Kramers (1975) $\mathrm{Pb}$ evolution curve (Fig. 11) and have an old crustal (i.e. radiogenic) signature. The feldspar lead isotope data together with the concordia upper intercept ages of 1.9
2.6 Ga indicate that the Mesozoic plutonic rocks in this part of the Ryongnam massif were derived from a Proterozoic to Archean crust.

\section{SUMMARY AND CONCLUSION}

The Mesozoic plutonic rocks of the Ryongnam massif in the Damyang-Geochang area were emplaced between 176-219 Ma (Table 4). Our data indicate three plutonic episodes: $219-212 \mathrm{Ma}$ 
and 187-183 Ma, when the foliated granitic to gabbroic rocks were emplaced, and a third period 177-176 Ma which was the time of emplacement of post-tectonic non-foliated plutonic felsic to mafic stocks. The ages reported for the foliated plutonic rocks conform to the field observations that these rocks did not form at the same time. Thus the 219-212 Ma plutons would be the result of plutonism associated with the Triassic Songnim Disturbance. The 187-183 Ma plutons belong to the Jurassic Daebo Orogeny, and the non-foliated plutons, ca. $177 \mathrm{Ma}$, must represent the waning stages of the Daebo Orogeny. The Cretaceous Bulguksa granites are absent in this area. The existence of non-foiated Daebo granites indicates that this region escaped the Bulguksa Disturbance. The zircon ages also indicate derivation from a Precambrian protolith of 1.9-2.6 Ga. The feldspar $\mathrm{Pb}$ isotopic data has a crustal signature. A gneiss from the Precambrian basement here has a U-Pb zircon age of $1935 \pm 4 \mathrm{Ma}$.

Acknowledgments - This research project was made possible by the financial support of Natural Sciences and Engineering Research Council of Canada (NSERC) and the Korean Science and Engineering Foundation (KOSEF). We would like to thank Professor Y. J. Kim, of Chonnam National University for his ongoing encouragement, and for supplying some of the samples. We also thank X. Wang who did part of the mass spectrometry, and J. B. Park, who assisted in the field work. A special and personal thanks go to B. K. Choi for much advice, support and encouragement during this study. We also thank the two Journal reviewers for their positive and constructive suggestions.

\section{REFERENCES}

Choo, S. H. and Kim, S. J. (1986) Rb-Sr age determinations on the Ryongnam massif (II): granitic gneiss and gneissose granite in the southwestern Jirisan region. Korean Inst. Energy Res., Research paper KR86-7, 7-33.

Hong, S. S., Kim, Y. J. and Kim, C. B. (1988) Petrochemical study on Namweon area. J. Geol. Soc. Korea 24 (special issue), 132-146.

Hong, Y. K. and Lee, B. J. (1989) Geochemical and microstructural studies on the Sunchang foliated granodiorite at a shear zone in the SW Part of the Okchon Fold belt, Korea. J. Geol. Soc. Korea 25,
294-311.

Kim, C. B. (1990) Petrochemical and geochronological study on the igneous rocks of the Jangsu area. $J$. Geol. Soc. Korea 26, 553-563.

Kim, C. B. and Kim, Y. J. (1984) Petrologic study on the so-called schistose granites in the northeastern part of Kwangju. J. Korean Inst. Mining Geol. 17, 197-214.

Kim, C. B. and Kim, Y. J. (1988) Petrological study on the igneous rocks between Janggye and Imsil, Chonbuk. J. Geol. Soc. Korea 24 (special issue), 87110.

Kim, C. B. and Kim, Y. J. (1990) Geochronology and petrochemistry of foliated granites between Damyang and Jinan. J. Korean Inst. Mining Geol. 23, 233-244.

Kim, C. B., Kim, Y. J. and Hong, S. S. (1990) Geochemical study on foliated granites in the DamyangJinan area. J. Korean Inst. Mining Geol. 23, 87-104.

Kim, O. J. (1971) Formation and evolution of a Jurassic granitic pluton in South Korea. J. Korean Inst. Mining Geol. 4, 1-10.

Kim, Y. J. (1986) Geochronology and petrogenesis of the older granitic rocks collected across the Ryongnam massif, Korea. J. Korean Inst. Mining Geol. 19 (special issue), 151-162.

Kim, Y. J., Kim, C. B. and Park, J. B. (1991) Petrochemistry and petrogenesis of foliated granites in the Honam shear zone, South Korea. J. Geol. Soc. Korea $27,52-63$.

Kim, Y. J. and Lee, C. S. (1988) The Study of igneous rocks and their igneous activity in the JangsooUnbong area. J. Geol. Soc. Korea 24 (special issue), 111-131.

Kim, Y. J., Park, Y. S., Choo, S. H. and Oh, M. S. (1989) The study on the igneous activity in the southwestern zone of the Ogcheon geoclinal belt, Korea (I): Namwean-Geochnag-Sangju area. J. Korean Inst. Mining Geol. 22, 117-127.

Krogh, T. E. (1973) A low contamination method for hydrothermal decomposition of zircon and extraction of $\mathrm{U}$ and $\mathrm{Pb}$ for isotopic age determinations. Geochim. Cosmochim. Acta 37, 485-494.

Krogh, T. E. (1982) Improved accuracy of U-Pb zircon ages by the creation of more concordant systems using an air abrasion technique. Geochim. Cosmochim. Acta 46, 637-649.

Lee, S. M. (1973) Application of metamorphic facies and facies series to the tectonics of Korea. J. Geol. Soc. Korea 9, 11-23.

Lee, S. M. (1980) Regional metamorphism of the metapelites in the Jirisan (Hadong-Sancheong) area. J. Geol. Soc. Korea 16, 1-15.

Ludwig, K. R. (1982) A computer program to convert raw $\mathrm{Pb}-\mathrm{U}-\mathrm{Th}$ isotope ratios to blank-corrected isotope 
ratios and concentrations, with associated errors and error-correlations. U.S. Geol. Surv., Open-file Report 82-820.

Ludwig, K. R. (1992) A plotting and regression program for radiogenic-isotope data, version 2. 57. U.S. Geol. Surv., Open-file Report 91-445.

Parrish, R. R. (1987) An improved micro-capsule for zircon dissolution in U-Pb geochrnology. Chem. Geol. (Isotope Geoscience Section) 66, 99-102.

Stacey, J. S. and Kramers, J. D. (1975) Approximation of terrestial lead isotope evolution by a two stage model. Earth Planet. Sci. Lett. 26, 207-221.

Steiger, R. H. and Jäger, E. (1977) Subcommission on Geochronology: Convention on the use of decay constants in geo- and cosmochronology. Earth Planet. Sci. Lett. 28, 359-362.

Turek, A., Sage, R. P. and Van Schmus, W. R. (1992) Advances in the U-Pb zircon geochronology of the Michipicoten greenstone belt, Superior Province, Ontario. Can. J. Earth Soc. 29, 1154-1165.

\section{APPENDIX: SAMPle DESCRIPTION AND LOCATION}

\section{Foliated granite $(\mathrm{KH}-4)$}

This is a coarse grained rock composed of: quartz (29\%), plagioclase (38\%), K-feldspar $(21 \%)$, biotite $(7 \%)$, and accessory minerals, titanite (1\%), apatite, zircon, allanite, opaques, and a small amounts of secondary minerals, chlorite $(2 \%)$, sericite, epidote $(1 \%)$, and calcite. Latitude $35^{\circ} 37^{\prime} 00^{\prime \prime} \mathrm{N}$, longitude $127^{\circ} 46^{\prime} 40^{\prime \prime} \mathrm{E}$.

\section{Foliated gabbro ( $\mathrm{KH}-2)$}

This is a coarse grained rock composed of quartz $(2 \%)$, plagioclase $(78 \%)$, pyroxene $(6 \%)$, hornblende $(9 \%)$, biotite $(3 \%)$, and accessory minerals: zoisite, zircon, apatite, opaques, and small amount of secondary minerals: sericite, chlorite and calcite. Latitude $35^{\circ} 40^{\prime} 00^{\prime \prime} \mathrm{N}$, longitude $127^{\circ} 41^{\prime} 30^{\prime \prime} \mathrm{E}$.

\section{Daegang foliated granite (FA-1)}

Composition of this pluton is granite to alkali granite. Sample is a coarse-grained alkali granite composed of quartz (37\%), alkali feldspar (46\%), plagioclase $(10 \%)$, biotite $(3 \%)$, reibeckite $(2 \%)$, accessory opaques, apatite, allanite, zircon, and a small amount of secondary chlorite and sericite. Latitude $35^{\circ} 19^{\prime} 00^{\prime \prime} \mathrm{N}$, longitude $127^{\circ} 15^{\prime} 00^{\prime \prime} \mathrm{E}$.

\section{Foliated granodiorite ( $\mathrm{FH}-1)$}

A coarse-grained rock with phenocrysts of hornblende. Composition is: quartz $(20 \%)$, plagioclase (50\%), K-feldspar (9\%), hornblende (3\%), biotite $(14 \%)$. Rest is titanite $(1 \%)$, apatite, allanite, zircon, and secondary epidote $(2 \%)$, sericite, chlorite, and calcite. Latitude $35^{\circ} 35^{\prime} 00^{\prime \prime} \mathrm{N}$, longitude $127^{\circ} 27^{\prime} 00^{\prime \prime} \mathrm{E}$.

\section{Sunchang foliated granite (FB-2)}

Composition is granite to granodiorite. Sample is a coarse-grained granodiorite made-up of quartz (28\%), plagioclase $(40 \%)$, K-feldspar $(19 \%)$, biotite $(5 \%)$, opaques, titanite $(1 \%)$, zircon, apatite, allanite, and secondary epidote $(2 \%)$, chlorite $(3 \%)$, and sericite. Latitude $35^{\circ} 27^{\prime} 00^{\prime \prime} \mathrm{N}$, longitude $127^{\circ} 14^{\prime} 00^{\prime \prime} \mathrm{E}$.

\section{Namweon granite ( $H B-1)$}

This is a granodiorite to granite pluton. Sample is a fine-grained granite composed of quartz $(25 \%)$, plagioclase $(42 \%), \mathrm{K}$-feldspar $(22 \%)$, biotite $(6 \%)$, hornblende $(2 \%)$, accessory opaques $(1 \%)$, titanite, zircon, apatite, allanite, and secondary myrmekite, chlorite, and sericite. Latitude $35^{\circ} 27^{\prime} 00^{\prime \prime} \mathrm{N}$, longitude $127^{\circ} 28^{\prime} 50^{\prime \prime} \mathrm{E}$.

\section{Diorite (KH-5)}

This medium to coarse grained rock is composed of quartz $(7 \%)$, plagioclase $(64 \%), \mathrm{K}$ feldspar $(5 \%)$, hornblende $(9 \%)$, biotite $(11 \%)$, accessory apatite, zoisite, allanite, opaques, and a small amount of secondary sericite, chlorite (1\%), epidote (1\%), and calcite. Latitude $35^{\circ} 37^{\prime} 30^{\prime \prime} \mathrm{N}$, longitude $127^{\circ} 50^{\prime} 00^{\prime \prime} \mathrm{E}$.

\section{Porphyroblastic gneiss (KJ-2)}

This is a massive coarsegrained rock with 5$12 \mathrm{~cm}$ porphyroblasts. It is composed of quartz, plagioclase, microcline, biotite, muscovite. Accessory minerals are apatite, zircon, opaques, and garnet. Secondary minerals are chlorite, sericite, and epidote. Latitude $35^{\circ} 23^{\prime} 46^{\prime \prime} \mathrm{N}$, longitude $127^{\circ} 36^{\prime} 14^{\prime \prime} \mathrm{E}$. 